\title{
Upaya Meningkatkan Kemampuan Bertanya Siswa dengan Pola Berjenjang dalam Pembelajaran PPKN di Kelas X IPA 3 SMA Negeri 2 Dompu Tahun Pembelajaran 2019/2020
}

\author{
Muhammad Amin \\ Guru SMA Negeri 2 Dompu, Kabupaten Dompu, Nusa Tenggara Barat \\ E-mail: muhammadamin.ntb@gmail.com
}

Article History: Received: 2020-09-14 || Revised: 2020-10-02 || Published: 2020-10-26

Sejarah Artikel : Diterima: 2020-11-17 || Direvisi: 2020-12-29 || Dipublikasi: 2021-01-06

\begin{abstract}
The purpose of this classroom action research is to increase the courage of students in asking questions during learning activities, to train and accustom students to good and scientific questions both in writing and orally and to find out / disclose data about tiered training patterns in an effort to improve students' questioning abilities. To achieve this goal, data from this classroom action research was collected through several actions. The technique used is through observation by using several sheets of observation tools in the form of a chech list list, action reflection assessment scores. Based on the observation data as shown in the tables above, we can say that the percentage and average score of the students of Class X IPA 3 SMA Negeri 2 Dompu are generally good. We can see this in the results of observations where in the first action the highest percentage was obtained, namely $42.9 \%$ on a score of 6.0 with 9 students, while in the second action the highest score was still at 6.0 with the number of students increasing to 18 people and the percentage was 8 $5.7 \%$ and in the third action there was a quite encouraging increase where the highest score was from 6.0 to 8.0 with 12 students, and the percentage was $57.1 \%$. So from 21 students who have been able to act or dare to ask questions both in writing and orally.
\end{abstract}

\section{Keywords: Tiered Exercise Patterns, Students' Questioning Ability}

\begin{abstract}
Abstrak
Tujuan Penelitian tindakan kelas ini yaitu untuk meningkatkan keberanian peserta didik dalam mengajukan pertanyaan - pertanyaan saat kegiatan pembelajaran berlangsung, melatih dan membiasakan diri peserta didik untuk menyusun pertanyaan yang baik dan ilmiah baik secara tertulis maupun secara lisan serta untuk mengetahui/mengungkapkan data tentang pola latihan berjenjang dalam upaya meningkatkan kemampuan bertanya siswa. Untuk mencapai tujuan tersebut data dari penelitian tindakan kelas ini, dikumpulkan melalui beberapa tindakan. Tehnik yang gunakan adalah melalui observasi dengan rnempergunakan beberapa lembar alat observasi berupa daftar chech list, skor penilaian refleksi tindakan. Berdasarkan data hasil observasi seperti yang ditunjukan pada tabeltabel tersebut di atas, dapatlah kita katakan bahwa Persentase dan skor rata-rata perolehan siswa Kelas X IPA 3 SMA Negeri 2 Dompu secara umum baik. Hal ini dapat kita lihat pada hasil observasi di mana pada tindakan pertama diperoleh Persentase tertinggi yaitu 42,9\% pada skor 6,0 dengan jumlah siswa 9 orang, sedang pada tindakan kedua skor tertinggi masih pada angkah 6,0 dengan jumlah siswa naik menjadi 18 orang dan prosentasenya adalah 8 5,7\% serta pada tindakan ketiga terjadi peningkatan yang cukup menggembirakan dimana skor tertinggi dari angka 6,0 menjadi skor 8,0 dengan jumlah siswanya 12 orang,dan prosentasenya adalah 57,1\%. Jadi dari 21 orang siswa yang telah mampu berbuat atau berani mengajukan pertanyaan baik secara tertulis maupun lisan.
\end{abstract}

Kata kunci: Pola Latihan Berjenjang, Kemampuan Bertanya Siswa

\section{PENDAHULUAN}

Titik Permulaan dalam proses belajar mengajar yang berhasil adalah membangkitkan minat dan kemampuan anak didik karena rangsangan bertanya, membawa kepada senangnya anak didik terhadap pelajaran, dan meningkatkan semangat mereka, serta meningkatkan kepentingan mata 
pelajaran bagi mereka disamping perasaan mereka, bahwa mereka mendapat manfaat dan kebanggaan dari kegiatan yang dengan sungguh-sungguh. Kurangnya kemampuan terhadap kegiatan pembelajaran, akan mengacaukan suasana dalam kelas dan timbulnya persoalan tentang peraturan, serta manjanya rasa malas dan lebih bosan ke dalam jiwa anak didik, disamping itu timbul rasa meremehkan pelajaran dan pekerjaan sekolah. Dengan demikian jelaslah betapa pentingnya meningkatkan kemampuan peserta didik dalam kegiatan pembelajaran bagi guru. Sebenarnya sebagian besar dari usaha seseorang guru yang sukses tertumpuh kepada bagaimana meningkatkan kemampuan khususnya berbicara dan bertanya di hadapan teman-temannya yang lain.

Sementara orang keliru dalam memahami arti meningkatkan kemampuan anak didik, disangkahnya hal itu dicapai dengan menggunakan berbagai daya tarik pada setiap pelajaran, menggunakan upaya atau rangsangan sementara, yang dapat menarik perhatian dan kemampuan peserta didik dalam berbagai waktu, hal ini nampak dalam kegiatan ceramah dalam mengajar; dimana guru hanya menjelaskan materi pelajaran, sementara peserta didik diam dan pasif mendengarkannya. Cara-cara seperti ini boleh jadi benar, akan tetapi seringkali mengecewakan, karena peserta didik akan segera bosan dan jenuh terhadap pelajaran dalam hal ini Kewarganegaraan, karena tidak menyentuh kebutuhan siswa dan tidak mengembangkan kemampuan untuk berbicara atau bertanya menanggapi hal-hal yang bagi siswa tidak sesuai dengan pemikirannya. Sebenarnya proses meningkatkan kemampuan siswa untuk bertanya jauh lebih luas dan dalam dari pada sekedar membuat rangsangan temporer dalam pelajaran. Karena ini bergantung pada sejauh mana pemaharnan dan pengetahuan guru terhadap sifat dan kemampuan peserta didik, dan penghargaan terhadap keperluan, dorongan dan bakat mereka yang semua itu dapat dimunculkan semuanya dalam kegiatan pembelajaran. Sesungguhnya kita para guru menyadari bahwa keperluan, dorongan dan bakat dan kemampuan peserta didik adalah potensi,yang dapat dikembangkan dan ditingkatkan oleh guru melalui kegiatan-kegiatan pembelajaran di kelas yang bermakna ke arah tujuan-tujuan tertentu, yang mereka ketahui sehingga siswa berusaha untuk mencapainya.

Berdasarkan hasil pengamatan di kelas, kenyataan menunjukan bahwa masih banyak di antara kita para guru khususnya guru PPKn, belum sepenuhnya menggunakan cara atau tehnik mengajar yang menyentuh kemampuan siswa utamanya berbicara dan bertanya tentang berbagai hal, yang ada hanyalah ceramah. Hal inilah nierupakan salah satu faktor penyebab minimnya motivasi belajar siswa dalam mengikuti Pembelajaran PPKn di kelas, sehingga pada gilirannya daya serap dan perolehan hasil belajar pada mata pelajaran PPKn di Kelas X IPA 3 SMA Negeri 2 Dompu belum mencapai terget yang diharapkan, Gambaran dan uraian dari latar belakang di atas serta kenyataankenyataan yang telah penulis kemukakan, maka berikut ini penilis mencoba mengangkat suatu penelitian tindakan kelas dengan judul: "Upaya Meningkatkan Kemampuan Bertanya Siswa Dalam Pembelajaran PPKn di Kelas X IPA 3 SMA Negeri 2 Dompu Tahun Pembelajaran 2019/2020. Tujuan dalam Penelitian tindakan kelas ini adalah Untuk meningkatkan keberanian peserta didik dalam mengajukan pertanyaan - pertanyaan saat kegiatan pembelajaran berlangsung serta, untuk melatih dan membiasakan diri peserta didik untuk menyusun pertanyaan yang baik dan ilmiah baik secara tertulis maupun secara lisan serta untuk mengetahui/mengungkapkan data tentang pola latihan berjenjang dalam upaya meningkatkan kemampuan bertanya siswa

\section{METODE PENELITIAN}

Jenis penelitian ini adalah Penelitian Tindakan Kelas (PTK). Subjek penelitian ini yaitu siswa di Kelas X IPA 3 SMA Negeri 2 Dompu, Tahun Tahun Pembelajaran 2019/2020, Penelitian dilaksanakan pada mata pelajaran PKKN. Menurut Sanjaya (2009:26), penelitian tindakan kelas merupakan proses pengkajian masalah pembelajaran di dalam kelas melalui refleksi diri dalam 
upaya untuk memecahkan masalah tersebut dengan cara melakukan berbagai tindakan yang terencana dalam situasi nyata serta menganalisis setiap pengaruh dari perlakuan tersebut. Penelitian tindakan kelas bertujuan untuk memperbaiki dan meningkatkan kualitas pembelajaran serta membantu memberdayakan guru dalam memecahkan masalah pembelajaran di sekolah. Sanjaya (2009:34-36) menyatakan bahwa penelitian tindakan kelas terbagi menjadi 4 manfaat sebagai berikut:

a. Manfaat untuk guru, yaitu:

1) PTK dapat meningkatkan kualitas pembelajaran yang menjadi tanggung jawabnya;

2) Melalui perbaikan dan peningkatan kinerja, maka akan tumbuh kepuasan dan rasa percaya diri yang dapat dijadikan modal untuk secara terus menerus meningkatkan kemampuan dan kinerjanya;

3) Keberhasilan PTK dapat berpengaruh terhadap guru lain;

4) PTK juga dapat mendorong guru untuk memiliki sikap profesional;

5) Guru akan mengikuti kemajuan ilmu pengetahuan dan teknologi.

b. Manfaat bagi siswa, yaitu:

1) Melalui PTK dapat mengurangi bahkan menghilangkan rasa jenuh dalam mengikuti proses pembelajaran;

2) PTK dapat berpengaruh positif terhadap pencapaian hasil belajar siswa.

c. Manfaat PTK untuk sekolah, dengan adanya guru-guru yang kreatif dan inovatif yang selalu berupaya meningkatkan hasil belajar siswa, akan membantu sekolah untuk mendidik siswanya.

d. Manfaat untuk perkembangan teori pendidikan, PTK yang bersifat kolaboratif antara setiap unsur yangberkepentingan termasuk kolaborasi antara guru dan orang LPTK, memiliki potensi untuk menerjemahkan teori yang bersifat konseptual ke dalam hal-hal yang bersifat riil dan praktis.

Dari beberapa pendapat yang telah dijelaskan, maka dapatdisimpulkan bahwa penelitian tindakan kelas adalah penelitian yang dilaksanakan dalam beberapa putaran waktu (siklus) di suatu tempat dimana terdapat sekumpulan siswa menerima pelajaran dari guru dengan tujuan untuk perbaikan atau meningkatkan mutu di kelas tersebut. Penelitian ini menggunakan siklus penelitian yang tercantum dalam Arikunto (2010:137) sebagai berikut.

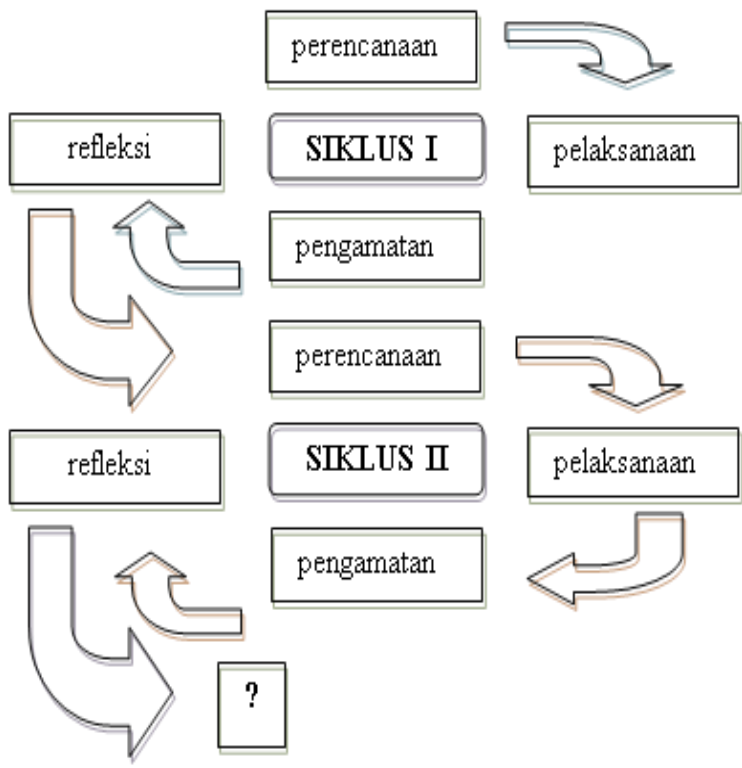

Gambar 1. Desain Penelitian Arikunto (2010:137) 
Penelitian ini dilaksanakan dalam tiga siklus, yang masing-masing siklus terdiri dari empat tahapan yaitu perencanaan, pelaksanaan, pengamatan dan refleksi. Siklus I dan siklus II dan III dilakukan untuk mengetahui aktivitas dan hasil belajar siswa. Jika pada siklus I aktivitas dan hasil belajar siswa yang diinginkan sudah tercapai atau telah terpenuhi berdasarkan kriteria yang ditetapkan, maka pembelajaran tetap dilanjutkan pada siklus II untuk memperbaiki kekurangankekurangan dan kelemahan pada siklus I. Akan tetapi jika dari tes akhir siklus I aktivitas dan hasil belajar siswa belum terpenuhi berdasarkan kriteria yang ditetapkan, maka akan dilanjutkan pada siklus II dengan terlebih dahulu merefleksi pembelajaran atau memperbaiki kekurangan yang terjadi pada siklus pertama, begitupun untuk siklus selanjutnya. Dalam membuat kesimpulan untuk menentukan apakah penelitian tindakan kelas tersebut sudah tuntas atau belum Persentase ketuntasan hasil belajar ditentukan dengan rumus:

$$
\mathrm{E}=\frac{\mathrm{n}}{\mathrm{N}} \times 100 \%
$$

Keterangan:

(Adaptasi dari Arikunto, 2013)

$\mathrm{E}=$ Persentase ketuntasan secara klasikal

$\mathrm{n}=$ Jumlah siswa yang tuntas belajar

$\mathrm{N}=$ Jumlah seluruh siswa yang diteliti

Kriteria keberhasilan dalam penelitian ini ditentukan berdasarkan hasil dari studi pendahuluan. Maka penelitian tindakan kelas yang dilakukan ini dikatakan telah memenuhi kriteria kesuksesan jika 75\% dari jumlah siswa keseluruhan memperoleh nilai minimum 75.

\section{HASIL DAN PEMBAHASAN}

\section{A. Hasil Penelitian}

Tabel Berikut ini menjelaskan tentang perolehan Skor hasil belajar siswa dalam kegiatan pembelajaran PPKn Khususnya dalam usaha meningkatkan kemampuan bertanya siswa, adapun perolehan skor yang dimaksud diantaranya yang memperoleh Skor tertinggi adalah 6 diraih oleh 9 orang siswa dengan presentase sebesar 42,9\%, Skor 5 diraih oleh 4 Orang siswa dengan presentase sebesar 19,0\% dan skor terendah adalah 4 diraih oleh 8 orang siswa dengan presentase sebesar $38,1 \%$. perolehan skor rata-rata siswa untuk tindakan pertama tersebut membuktikan bahwa masih banyak siswa Kelas X yang harus ditingkatkan lagi kemampuannya, kesimpulan dalam pelaksanaan siklus pertama yaitu jumlah siswa yang berhasil dalam kegiatan kemampuan bertanya pada tindakan pertama adalah yang memperoleh skor 6,0 ke atas, yaitu 9 orang siswa atau 42,9\% dan yang gagal atau yang harus ditingkatkan lagi adalah yang memperoleh skor 5,0 ke bawah; yaitu 12 orang siswa atau $57,1 \%$.

Tabel 1. Persentase perolehan skor pada tindakan Pertama.

\begin{tabular}{cccc}
\hline No & $\begin{array}{c}\text { Skor (Hasil } \\
\text { Belajar) }\end{array}$ & $\begin{array}{c}\text { Jumlah Siswa (Dalam } \\
\text { Capaian Skor) }\end{array}$ & $\begin{array}{c}\text { Rata-rata } \\
\text { (Persentase) }\end{array}$ \\
\hline 1 & 9 & - & - \\
\hline 2 & 8 & - & - \\
\hline 3 & 7 & 9 & $42,9 \%$ \\
\hline 4 & 6 & 4 & $19,0 \%$ \\
\hline 5 & 5 & 8 & $38,1 \%$ \\
\hline 6 & 4 & - & - \\
\hline 7 & 3 & - & - \\
\hline & Jumlah & 21 & $100 \%$ \\
\hline
\end{tabular}


Melihat kesenjangan antara yang berhasil dan yang masih gagal, maka peneliti melakukan kegiatan berupa motivasi untuk lebih berperan aktif dalam kegiatan dan melatih siswa untuk menulis pertanyaan-pertanyaan yang termasuk dalam kategori mudah secara bertahap kekategori sedang dan akhirnya mereka mampu mengungkapkannya tanpa melihat konsep atau catatan serta menumbuhkan keberanian untuk berbicara walaupun hanya satu kalimat. Selanjutnya penulis kemukakan data hasil kegiatan observasi tindakan kedua seperti pada tabel berikut ini :

Tabel 2. Persentase perolehan skor pada tindakan Kedua.

\begin{tabular}{cccc} 
No & $\begin{array}{c}\text { Skor (Hasil } \\
\text { Belajar) }\end{array}$ & $\begin{array}{c}\text { Jumlah Siswa (Dalam } \\
\text { Capaian Skor) }\end{array}$ & $\begin{array}{c}\text { Rata-rata } \\
\text { (Persentase) }\end{array}$ \\
\hline 1 & 9 & - & - \\
\hline 2 & 8 & - & - \\
\hline 3 & 7 & - & - \\
\hline 4 & 6 & 18 & $85,7 \%$ \\
\hline 5 & 5 & - & - \\
\hline 6 & 4 & 5 & - \\
\hline 7 & 3 & - & $100 \%$ \\
\hline & Jumlah & 21 &
\end{tabular}

Tabel diatas menunjukan bahwa skor tertinggi masih pada 6 diraih 18 orang siswa dengan skor rata-rata 85,7 atau bertambah 9 orang siswa, sedangkan skor terendah 4 diraih 5 orang siswa atau rata-rata 23,8. Hasil pelaksanaan tindakan pada siklus kedua terjadi peningkatan jumlah siswa yang berhasil, dimana pada tindakan pertama siswa yang berhasil hanya diraih 9 orang siswa, namun pada tindakan kedua ini bertambah menjadi 18 orang siswa yang termasuk kategori berhasil dengan skor perolehan yaitu 18 atau naik 85,7\%. Disisi lain masih terdapat siswa yang masih gagal yaitu sejumlah 5 orang siswa atau 23,8\%. Untuk itu penulis melaksanakan siklus ketiga berupa dengan beberapa kegiatan diantaranya mengumpulkan fakta dari materi yang diajarkan. kedua, menemukan masalah-masalah apa saja yang tersirat atau terstwat dalam isi materi tentang "Prestasi Diri " dan yang ketiga, bagaimana merumuskan suatu gagasan yang ada dalam pemahaman pikiran untuk diungkapkan dan terakhir adalah bagaimana siswa itu mengingat gagasan-gagasan yang ada itu untuk diungkapkan tanpa melihat konsep yang telah disiapkan sebelumnya. Kemudian untuk membuktikan sudah sejauh manakah hasil dari kegiatan ketiga ini, penulis akan disajikan pada tabel berikut ini:

Tabel 3. Persentase perolehan skor pada tindakan Ketiga

\begin{tabular}{cccc}
\hline No & $\begin{array}{c}\text { Skor (Hasil } \\
\text { Belajar) }\end{array}$ & $\begin{array}{c}\text { Jumlah Siswa (Dalam } \\
\text { Capaian Skor) }\end{array}$ & $\begin{array}{c}\text { Rata-rata } \\
\text { (Persentase) }\end{array}$ \\
\hline 1 & 9 & - & - \\
\hline 2 & 8 & 12 & $57,1 \%$ \\
\hline 3 & 7 & - & - \\
\hline 4 & 6 & 9 & $42,9 \%$ \\
\hline 5 & 5 & - & - \\
\hline 6 & 4 & - & - \\
\hline 7 & 3 & - & - \\
\hline & Jumlah & 21 & $100 \%$ \\
\hline
\end{tabular}

Dari hasil kegiatan observasi tindakan ketiga ini, nampaknya terjadi peningkatan yang cukup memuaskan dimana pada tindakan kedua skor tertinggi adalah 8, namun dengan tehnik yang 
penulis lakukan sehingga pada tindakan ketiga ini naik hampir beberapa persen. Selanjutnya dari data tabel di atas dapat dilihat dimana skor tertinggi yaitu 8 diperoleh 12 orang siswa, dengan rata-rata peroleh 57,1 sedang skor terendah adalah skor 6 dengan rata-rata 42,9 sehingga dari uraian ini dapat dilihat bahwa termasuk kategori berhasil (Tuntas secara klasikal) dan dianggap telah selesai namun dalam prosesnya dimasa yang akan dating hasil belajar harus lebih ditingkatkan lagi kegiatan, berikut disajikan rekapitulasi perbangingan perolehan skor dan presentase antar tindakan I, II, dan III.

Tabel 4. Rekapitulasi Perbandingan perolehan skor dan persentase antar tindakan (I,II,III)

\begin{tabular}{|c|c|c|c|c|c|c|c|}
\hline \multirow[t]{2}{*}{ No } & \multirow{2}{*}{$\begin{array}{l}\text { Skor (Hasil } \\
\text { Belajar) }\end{array}$} & \multicolumn{3}{|c|}{$\begin{array}{c}\text { Jumlah Siswa (Dalam } \\
\text { Capaian Skor) }\end{array}$} & \multicolumn{3}{|c|}{ Rata-rata (Persentase) } \\
\hline & & I & II & III & I & II & III \\
\hline 1 & 9 & - & - & - & - & - & - \\
\hline 2 & 8 & - & - & - & - & - & - \\
\hline 3 & 7 & 9 & - & - & $42,9 \%$ & - & - \\
\hline 4 & 6 & 4 & 18 & 18 & $19,0 \%$ & $85,7 \%$ & $85,7 \%$ \\
\hline 5 & 5 & 8 & - & - & $38,1 \%$ & - & - \\
\hline 6 & 4 & - & 5 & 5 & - & $23,8 \%$ & $23,8 \%$ \\
\hline 7 & 3 & - & - & - & - & - & - \\
\hline & Jumlah & 21 & 21 & 21 & $100 \%$ & $100 \%$ & $100 \%$ \\
\hline
\end{tabular}

Menunjuk pada tabel diatas dapat dilihat bahwa perubahan skor dari tindakan pertama, kedua dan ketiga yang mengalami peningkatan hasil belajar maka dapat disimpulkan bahwa penelitian tindakan kelas yang dilakukan dianggap berhasil.

\section{B. Pembahasan}

Berdasarkan data hasil penelitian seperti yang ditunjukan pada tabel-tabel yang terdapat pada bagian hasil penelitian di atas, dapat disimpulkan bahwa Persentase dan skor rata-rata perolehan siswa Kelas X IPA 3 SMA Negeri 2 Dompu secara umum baik. Hal ini dapat kita lihat pada hasil observasi di mana pada tindakan pertama diperoleh Persentase tertinggi yaitu 42,9\% pada skor 6,0 dengan jumlah siswa 9 orang, sedang pada tindakan kedua skor tertinggi masih pada angkah 6,0 dengan jumlah siswa naik menjadi 18 orang dan prosentasenya adalah 8 5,7\% serta pada tindakan ketiga terjadi peningkatan yang cukup menggembirakan dimana skor tertinggi dari angka 6,0 menjadi skor 8,0 dengan jumlah siswanya 12 orang,dan prosentasenya adalah 57,1\%. Jadi dari 21 orang siswa yang telah mampu berbuat atau berani mengajukan pertanyaan baik secara tertulis maupun lisan. Adapun perlakukan yang dilakukan oleh peneliti untuk meningkatkan kemampuan bertanya siswa khususnya 9 orang siswa yang masih kurang tersebut adalah berupa remedial atau pengayaan tentang tehnik-tehnik bertanya, jadi siswa diberi bahan sederhana kemudian menyusun 10 buah pertanyaan, yang selanjutnya mereka akan bacakan pada pertemuan-pertemuan berikutnya.

\section{SIMPULAN DAN SARAN}

\section{A. Simpulan}

Secara umum dapatlah penulis kemukakan bahwa, hasil penelitian ini ternyata pola latihan berjenjang yaitu membaca konsep, latihan merumuskan pertanyaan tanpa melihat konsep merupakan cara yang paling tepat dalam melatih kemampuan bertanya siswa secara maksimal, maka untuk itu penulis mengambil kesimpulan sebagai berikut:

a) Pola latihan berjenjang dapat meningkatkan kemampuan bertanya siswa khususnya di Kelas X IPA 3 SMA Negeri 2 Dompu dalam Pembelajaran PPKn. Hal ini dapat ditunjukan 
pada perolehan skor rata-rata yaitu 8,3 dari 21 orang siswa.

b) Teknik latihan bertanya dengan berpedoman pada kata-kata "apakah, siapakah, mengapa, dan bagaimana merupakau awal yang baik dalam melatih siswa untuk bertanya.

c) Dalam Pembelajaran PPKn khususnya kemampuan bertanya ditemukan kendala berupa keterbatasan buku-buku pelengkap, rendahnya minat dan motivasi belajar serta kurangnya siswa melatih bertanya dan berbicara di hadapan teman-teman yang lain.

\section{B. Saran}

a) Rekan-rakan guru khususnya di Kelas X IPA 3 SMA Negeri 2 Dompu, agar selalu melatih siswa untuk bertanya dan berikan motivasi agar berani berbicara di hadapan temantemannya.

b) Untuk waktu yang akan datang perlu diadakan penelitian yang secara intensif tentang bagaimana meningkatkan minat dan motivasi siswa untuk berani berbicara dan dilatih memecahkan suatu permasalahan dalam kegiatan belajar mengajar di kelas.

\section{DAFTAR RUJUKAN}

Anni, Catharina Tri, dkk. 2006. Psikologi Belajar. Semarang: UNNES Press.

Arikunto, Suharsimi. 2006. Prosedur Penelitian Suatu Pendekatan Praktik. Jakarta: Rineka Cipta.

Dimyati dan Mudjijono. 1999. Belajar dan Pembelajaran. Jakarta: Rineka Cipta.

Elviana, F., Fakar, A., \& Bulan, A. 2020. Pendidikan Karakter dan Pengajaran dengan Metode Demonstrasi untuk Kemajuan Belajar Generasi Millenial. Prosiding Seminar Nasional IPPeMas 2020, 1(1), 702-706. Sumbawa: LPPM Universitas Samawa.

Faidah, C. N. 2018. Dekonstruksi Sastra Anak: Mengubah Paradigma Kekerasan dan Seksualitas pada Karya Sastra Anak Indonesia. Jurnal Kredo, 2(1), 126-139.

Fathirma'ruf, F., \& M. Said, B. (2020). Pengembangan Perangkat Pembelajaran Konstruktivistik Model Teaching with Analogies (TWA) pada Mata Kuliah Database Management System (DBMS) untuk Meningkatkan Kemampuan Berpikir Kreatif Mahasiwa. Jurnal Teknologi Informasi dan Ilmu Komputer, 7(5), 1051-1060. doi:http://dx.doi.org/10.25126/jtiik.2020752388

Hamalik, Oemar. 2009. Proses Belajar Mengajar. Jakarta: PT. Bumi Aksara.

Hamdani. 2011. Strategi Beajar Mengajar. Bandung:

Junaini, E., Agustina, E., \& Canrhas, A. 2017. Analisis Nilai Pendidikan Karakter Pada Cerita Rakyat Seluma. Jurnal Korpus, 1(1), 39-43.

Kemendikbud. 2011. Pedoman Pelaksanaan Pendidikan Karakter. Jakarta: Pusat Kurikulum Kemendikbud RI.

Lie, Anita. 2004. Cooperative Learning, Mempraktekan Cooperative Learning di Ruang-ruang kelas. Jakarta: Grasindo.

Ratumanan, Gerson, Tanwey. (2011). Penilaian Hasil Belajar Pada Tingkat Satuan Pendidikan Edisi 2. Surabaya: Unesa University Press.

Sari, E.K. 2017. Peningkatan Sikap Menghargai Pendapat dan Prestasi Belajar Siswa Materi Menghargai Keputusan Bersama Melalui VCT Gejala Kontinum Di Kelas V SD Negeri 2 Karang Tengah. Skripsi. Tidak Diterbitkan. Universitas Muhammadiyah Purwokerto.

Sugiyono. 2011. Teknik penelitian kuantitatif, kualitatif dan r \& d. Bandung: Alfabeta. 